A N NALES

UNIVERSITATIS MARIAE CURIE-SKŁODOWSKA LUBLIN - POLONIA

VOL. XXIX, 2

SECTIO J

2016

Drohobych Ivan Franko State Pedagogical University, Ukraine

\title{
NADIYA DUDNYK
}

nadija.d@mail.ru

\section{Usage of Project Method in Preschool Education}

Wykorzystanie metody projektu w edukacji przedszkolnej

\begin{abstract}
The method of psychological and pedagogical design in the process of a teacher work with children under school age is examined in this article. This method is applied by teachers due to the current need for innovation in the process of children's development. Using this method is also determined by the requirements for the teachers in organisation of the educational process. It is also presented the method of phased realization of the activity with the help of the project method.
\end{abstract}

Key words: method of projects; education of a child; specialization; individual development

\section{INTRODUCTION}

Innovative potential of a society plays a special role on the contemporary level of the development of civilization, calling for people capable of creative thinking and quick finding the necessary information, as well as making optimum constructive decisions and creating essentially new ideas in different fields of knowledge. And this, for its part, forms the social order for new approaches in the education system and new pedagogical thinking.

As a result of strengthening democratic tendencies in societies, their educational systems, which make up their most indispensable component, started to shift the accent from the mass pedagogical phenomena to the personality of a child and to the conditions of its self-disclosing and self-realization at different 
stages of its vital functioning. The tendency of educational systems' orientation to a personality finds its manifestation also in pedagogical education.

Since recent years, Ukraine's contemporary education system has attached a special importance to the development of preschool pedagogy as a main link in the formation of a person and, thus, the country's future. Actually, it is in preschool childhood that the foundation for the child's general abilities is laid as a launching pad for the child's acquisition of scientific knowledge, mastering of skills, and formation of his or her own views and convictions in the future. Therefore, the system of development of preschool education is now witnessing essential changes. Intensive development of public life and active penetration into all its spheres of scientific and technical progress demands from a preschool teacher his or her selection of the most effective means of training and education on the basis of contemporary methods and integrated technologies.

The development of informative interest in various fields of knowledge and kinds of activity are key components of successful training of children at school. Preschool children's interest in the surrounding world and desire to study and learn about everything new is the basis of formation of this quality.

\section{THE PROBLEM'S TOPICALITY}

Under the influence of the active search for the most effective methods and technologies in the $21^{\text {st }}$ century, which were aimed at providing efficiency, quality and productivity of the educational process, the advancing development of a child and formation of a creative personality, which is able to project and organize a child's life, as well as to expediently transform the world around, have become the main point of focus. The wide experience and success of the European and American educators together with the fruitful research work of Ukraine's domestic scientists enable practical teachers to develop and introduce new and alternative approaches to education and training of children in accordance with the contemporary social requirements.

The significance of disclosing and maximum realization of each personality's creative abilities is underlined in the following state documents: "The National Doctrine of Development of Education in Ukraine", the laws of Ukraine "On Education", "On Preschool Education", "State Component of Preschool Education", the base program of development of a child "I in the World", etc.

The Law of Ukraine "On Preschool Education" emphasizes the necessity of modernization of the earliest stage of education, improvement of its content, improvement of teaching and educational technologies and their compliance with all contemporary requirements. In the Comment to the "Basic Component of Preschool Education in Ukraine" and "Basic Program of Development of a Child "I in the World" the updated purpose and priorities of development of preschool 
education are outlined (quote): "The contemporary preschool education should bear the character of innovative activity. Its priority-driven development direction is the widening use of contemporary educational and educational technologies (...)" (Bazova... 2008, p. 16).

One of the most popular methods in preschool innovative pedagogy is the method of projects, in particular - the technology of preschool pedagogical designing, which integrally unites the achievements of psychologists, creative teachers, methodologists, and the knowledge of specialists in history of pedagogy, thus, accumulating the abovementioned technology which can be applied in compliance with contemporary educational requirements.

\section{PRESENTATION OF THE BASIC MATERIAL}

The evolution of the method of projects in Ukrainian pedagogy is inseparable from the names of such national educators as V. Shulhina, M. Krupenina, V. Ihnatiyeva, S. Shats'kyi, and others. R. Kurbatov contributed to this his innovative method, based on pedagogy of cooperation techniques and constructed on the synthesis of the method of projects and the "school of dialogue between cultures", aiming at the introduction of the integrated educational knowledge.

For the recent decades, in connection with the introduction of personalityfocused education paradigms, the method of projects has been enduring its rebirth as an effective pedagogical technology. Many methodologists and educators share their individual experience in the practical use of the method of projects on the pages of pedagogical journal "Preschool Education" more and more frequently, among them H. Hradets'ka, S. Semak, A. Romashkina, V. Kocherhina, L.Novits'ka, M. Veraksa, H. Pantyelyeyev, and L. Morozova. Their publications concretize the scientific elaborations of T. Pirozhenko, S. Ladyvir, L. Kaluz'ka, M. Otroshchenko, L. Fesiukova, O. Marinushkin, H. Shubina, and I. Dychkivs'ka, which makes it possible to call the method of psychological-pedagogical designing perspective in the development of contemporary preschool education.

In the corresponding literature the notion of "educational project" is interpreted rather in a different way, as:

- "the didactic means of encouraging of cognitive activity, development of creativeness and, simultaneously, formation of certain individual qualities" (H. Selevko);

- "the form of class organization, which provides a complex character of activity of all its participants aiming to obtain educational product per certain time, ranging from several months to one study year" (M. Skatkin);

- "a well-reasoned conscious activity directed to the formation of a system of intellectual and practical abilities in children" (S. Honcharenko); 
- "an independently designed as an idea and self-made product (material or intellectual) as its embodiment prepared under the control and with the consultations of an adult" (O. Savchenko);

- "an educational and work task which stirs up the pupils' activity resulting in their creation of a product which possesses its own subjective and, sometimes, objective novelty" (P. Pidkasystyi).

According to E. Polat, who is a leading teacher of our contemporaneity and the method of projects investigator, at the base of each didactic category, or the "educational project, lies the development of informative habits of children, their ability to independently build up their own knowledge and orientation in the information space, and also the development of critical and creative thinking. From this point of view, the applied activity is a set of ways and operations of mastering of a certain sphere of knowledge, whether practical or theoretical. It is a mode of organization of cognition process for a preschool educational institution. The method of projects is a special kind of training and informative activity of its pupils directed to the solution of a problem, connected with the creation of an educational product possessing subjective or objective value and able to be considered as a way of organization of such an activity $(2009$, p. 5).

As a pedagogical idea, a technology and a form of study, the method of projects is alternative to the traditional education system.

As it should be spoken, childhood is an autonomous part of human life. This means that preschool education should give not only the knowledge necessary for adult life in the future, but also the knowledge, skills and habits capable - already today - of helping a child with the solution of his or her urgent vital problems.

In addition, the contemporary pedagogical workers of preschool educational institutions should remember that a child has come to the kindergarten not so much to study, but just to live in it.

"The overall objective of the national preschool education is to create favourable conditions for the personal formation and creative self-realization of every child, evolution of its vital competence, and development of his or her evaluative attitude to the world of Nature, Culture, People, and Himself or Herself" (Bazova... 2008, p. 23).

Analysing the history of the method of projects' development, we will specify that it is not something essentially new in the world of pedagogy. It was constructed in the first half of the $20^{\text {th }}$ century on the basis of the pedagogical ideas of humanism as represented by an American philosopher and educator John Dewey (1859-1952), who was the founder of pedagogy of pragmatism and who named his technique "a method of problems". Its essence can be revealed consequently: true is all that is useful. The central figure in Dewey's training process is a child, and he considered childhood not just as the preparation for one's life, but as the 
full-value life itself, whereas the process of one's training and development is, in fact, the resolution of antagonisms (Chepil and Dudnyk 2012, p. 88).

Based on Dewey's concept, another American educator W. Kilpatrick developed his designing education system. As the purpose of his method of projects, he considered the introduction of education of a person who is able to work constantly, take the initiative in work, issue practical tasks on a large scale and fulfils them. Dewey's and Kilpatrick's ideas gained popularity within American and European schools thanks to rational association of theoretical knowledge with its practical application.

The method of projects is the organization of teaching and educational activity during which its participants acquire knowledge in the course of planning and performance of practical problems-projects. It is a didactic means of encouraging cognitive activity of a child, development of his or her creative thinking and formation of his or her individual qualities, otherwise latent. Independence, activity, and productivity are the three foundations on which this method of training is based. The project gives a chance to closely connect up theory with practice. A child starts understanding, that "everything I learn, I can understand, I know why this is necessary for me and where I can apply my knowledge" (Karatayeva 2004, p. 8).

During the implementation of the method of projects, a variety of problems get solved, including the acquisition of informative habits, abilities to independently cherish one's knowledge and to orient in information space, active development of critical thinking, extension of sphere of communications, etc.

The explanation of the method of projects should take into account the expansion of its application field from learning to education in the development of a child's personality: it is a way of organization of the pedagogical process based on the interaction between a teacher and his pupil within their environment. The carrying out of the project implies a stage-by-stage practical activity aimed at achieving a specified purpose.

Within the project its participants become the basic characters of a teaching and educational process, equal in rights members of a creative collective, that help them to unite in accordance with their interests and provides a variety of role activity. The method gives the chance to involve in an informative process not only children's thought, but also their emotions. During the project's realization they learn to give help to their colleagues, develop the ability to think independently, make their own assumptions and react to the thoughts of their friends, form call of duty and responsibility, independently extend knowledge, and mature critical and creative thinking.

Outstanding Ukrainian educationalist Vasyl Sukhomlyns'ky was of the opinion that the educational process in contemporary education should develop in children the all-powerful pleasure of knowledge, and the school (together with 
kindergarten) can be the true house of joy. It is necessary to know and develop informative interests of children in order to carry out this requirement. Informative activity of a person is a precondition of someone's spiritual development. Mastering the spiritual culture of a society considerably influences the hierarchy of requirements, motives, and interests of the subject who, in turn, stipulates not only the quality of one's professional work, but the character of one's leisure activities as well. This, on the one hand, is the condition for a person's satisfaction of his or her spiritual needs, and, on the other hand, is the way of a person's self-realization.

The formation of a child's informative activity closely connected with the development of his or her conscientiousness, decision independence, initiative, strength of will and other traits of character, because activity as a human quality assumes that a pupil becomes a subject of work and is in charge of his or her own development taking into account the universal values and society requirements.

The main goal of the method of projects in preschool educational institutions is the development of a free creative personality which is modified by development tasks and problems of research activity of children.

Development problems of the method of projects:

- securing children's psychological well-being and health;

- development of informative abilities;

- development of creative imagination;

- development of creative thinking;

- formation of communicative habits.

In the contemporary educational technology of psychological and pedagogical designing (P3 technology), authors of which are T. Pirozhenko and S. Ladyvir, the main ideas of the already known and completely new methods and modes (such as: thematic planning, creative tasks, motivation of activity, generalization, problem situations) are methodically grounded and united into a flexible system. As a matter of fact, we understand a system as such a set of separate elements which, when assembled, acquire an essentially new quality accented on the independent, active and motivated work of a child (Ladyvir 2007, p. 14).

To design a pedagogical process means to project the teacher's and pupil's activity in their interaction. Such designing of an individual development system becomes a model of an integral project. Its components are psychological and pedagogical diagnostics of physical, mental, and social development of a child; that is outlining of pedagogical problems; organization of general activity of a teacher and his pupils; monitoring and correction of dynamics of children's levels of activity; and analysis and anticipation of educational situations of interpersonal cooperation on individual and group levels.

Thus, psychological-pedagogical designing (P-3 technology) is a project of joining activities of adults and children, in which a child's wish and aspiration as well as the pedagogical variability of forms, methods, means and development 
influence the teacher and combine with the psychological regulations of natural development of the children's with adults' common activities (from a wishful intention to the creative level of a plan's realization).

Doctor of pedagogical sciences K. Krutiy, in the "Concept and Methodical Bases of »A Child of Preschool Age« Program", remarks that a person's social development takes place in two interconnected directions, namely - socialization (mastering of social experience) and individualization (acquiring of relatively independent autonomy) (Polat 2009, p. 5).

The problem of socialization of a person at the stage of preschool childhood becomes especially topical today. According to the investigations of the latest decade (S. Lytvynenko, S. Kurinna, T. Pirozhenko, T. Ponimans'ka, and others), the senior preschool age is seen as the final stage of the initial link of socialization of a person at the preschool educational institution level, as a sensitive period for mastering the whole of public norms. As a matter of fact, socialization means the inclusion of a preschool child into a certain social community, group or children's collective, from whom the child learns, recognizes its own laws, norms and existence rules, and finally, gets adapted in the society harmoniously.

With time (in the past, present, future) the child's interest in himself or herself becomes constantly stronger. Not only does the child ask an adult for the stories about his or her past, but also recollects them independently. The child estimates his or her past events objectively, with critical remarks. The child thinks about the future with a hope and, having committed no misdeeds in it, believes his or her wishes will come true. The child perceives the past, the present and the future as a possibility to self-realization in life in all time dimensions. Due to that, the prospect that opens in front of the child, becomes the child's acquisition and determines the development of his or her individuality. The child together with close adult relatives construct the project of his or her future in accordance with which he or she sees himself or herself as kind and successful, healthy and strong-willed, clever and attractive, as one who will always takes care of the relatives and loves the mum, and will make everything that someone can to maintain peace and avoid war on the planet so that all could be healthy and happy, whereas he or she could peacefully work as a teacher, a doctor, a gardener, etc. (Pirozhenko 2006, p. 9).

A pedagogue is the co-coordinator of designing activity. He or she has to understand that one's success in the contemporary world is in many respects defined by one's ability to organize one's own life as a project. That is: to define its far and close prospects, to outline the plan of actions and resources to be accomplished and - after its realization - to estimate whether or not one has managed to achieve the completion in view.

For the successful introduction of a designing activity into children's collective the educationalist should transform from a teacher to an assistant, an advisor, who is always not "above", but "near" the child. It is important that among the 
participants of the teaching and educational process should dominate a democratic style of mutual relations that provide: the understanding and acceptance of a preschool child such as he or she actually is, a manifestation of respect for the child's parents, who are also the participants of the project, and granting them a sort of pedagogical support.

In order to prepare for the introduction of the project a pedagogue should do the following:

- determine the project's theme on the basis of studying children's interests;

- develop, taking into account the algorithm of a projected activity, a rough course of the project directed to achieve its aim;

- acquaint the parents with the project's theme, create the conditions for setting up the problem necessary for the organization of the project activity;

- collect and accumulate the material for various kinds of children's activity;

- in case of necessity, involve the experts (musical director, psychologist, and others) into the realization of the corresponding sections of the project;

- roughly determine the final results for the total presentation (Dytyna 2000, p. 40).

The activity of teachers as well as of children can be specified and supplemented during the whole process. The method of project's technique implies a system of stage-by-stage activity of children and their teacher according to a certain algorithm.

At stage I, the teacher does the greatest activity. He creates such situations which arouse curiosity by the planned theme and emotional elevation of children. Afterwards, the teacher finds out what the children earned and mastered in their activity within this theme.

A problematic situation created by the teacher successfully is necessary as a push for acquisition of new knowledge or instigation to the other way of action; in addition, it stirs up a child's cognitive activity. It can also be a conversation concerning a problem situation or a piece of belles-lettres, a photo of an unusual house, national symbols, a meeting with an interesting person, and a socially significant event. Facing a problem brings a child to the necessity of resolving antagonisms, and involves him or her into an active search, arousing inquisitiveness. Its problematical character provides a child's constant openness to everything new. The first stage ends with the definition of the purpose.

At stage II, children put forward various suggestions aimed at the solution of the set up problem. At this stage, everything which expands knowledge or improves children's skills is planned, and the placement of each project participant is defined. The teacher should become just the co-coordinator of activity, but not its direct initiator or leader. 
When discussing with children the course of the project the teacher consistently suggests the selection of activity content:

1. What do we want to learn about and what can we learn?

2. From whom to get the information about the theme interesting to children and where to search it?

3. What should we do in order to investigate the interesting material of the project's theme and what product shall we create as a result?

The teacher plays the part of an assistant and a listener. However, he or she can express a viewpoint of the situation, giving children a push to new meditations, and offering his alternative option of the activity.

At stage III, takes place a practical embodiment of the project (there). Children work individually, in subgroups, with the chosen by themselves materials of various kinds of activity. During the elaboration of the project theme, there can take place the correction of the plan due to unexpected obstacles or conclusions. Parents also can be involved in the work on the project.

Stage IV is a presentation of the product. The presentation form should be attractive, interesting and well thought over; it should reflect each child's contribution, as well as that of parents' and teachers'. Special guests can also be invited to the presentation. At this moment the summit of emotional tension occurs, which should be intensified by emphasizing the social importance of the project.

Stage $\mathrm{V}$ is the project's final stage. It is dedicated to the analysis of the project's evolution. However, this is not one's report to the teacher and other children on "what I did or remembered", but rather a reminiscence - supported by symbols and project products - of how everybody worked over it, the introspection of one's work and findings, revelation of new wishes and challenges, satisfaction from work, and collective activity. In the course of discussion there can appear new problems that will give a push to a new project.

At each stage of the project activity, communication takes place there. Thanks to the application of various techniques a child receives helpful information, finds out new knowledge and facts, and makes discoveries of his or her individual values. In this way a child improves his or her mental operations (analysis, concrete definitions, comparisons, systematization, generalization, etc.). A child shares the emotions and feelings to the others, sustaining the experience of working in a group. Mutual relations among the participants of a project activity are regulated by communicative measures that influence the formation of a person's moral bases and develop socializing abilities of children. Communication with others induces them to self-knowledge. Due to the real effect of the result of a child's project activity, the child has an excellent opportunity to feel satisfaction from his or her own work. This also promotes the formation and development of important motives of activity - social, informative, personal, etc. 
Thus, the last thing a teacher should do is to indicate a pupil what to study: its none of his, but his pupil's business to want, to search and to find, whereas his task is to make the training accessible to a child, to artificially stimulate a child's desire to study and to give him or her the means to satisfy it. The precondition for productive activity of children that will cause a motivation to cooperate is the creation of the emotionally positive microclimate and cognitive interest in the group. Therefore, the method of projects can only be successfully realized under condition of the methodical training of teachers, educational work with parents, and creation of subject-development environment.

When using the method of projects in the work with senior preschool children, it is necessary to remember that the project is a product of cooperation, co-authorship of tutors, children, parents and, sometimes, all the personnel of a kindergarten. Therefore, the project theme, its form and the plan of action are developed collectively. At this stage of development of the content of employment, games, walks, observations, excursions and other kinds of activity connected with the theme of the project, it is important that the teachers should carefully think over and organize the subject environment in preschool educational institutions (PEI) so that it could be a "background" for children's heuristic and search activity (Ladyvir 2007, p. 14).

It is necessary to involve the children's parents and relatives into the organization of the formers' search and creative activity, because they themselves will hardly cope with this activity alone. The teacher suggests children a task concerning the theme of a project. Children together with their parents choose the task themselves. But before distributing the tasks, the teacher is obliged to think them over thoroughly. It is important that they are not capacious and can be carried out with readiness and pleasure, and, if necessary, the teacher can supply the children with the supporting practical material, and then recommend where it can be found.

\section{CONCLUSIONS}

Mastering by a child of his or her abilities and habits of self-development as a personality is one of basic educational problems. This problem can be solved effectively by the introduction of innovative technologies, in particular - by the help of the method of projects.

The method of designing (or: projecting) activity is very perspective in contemporary education. Taking the personality-oriented approach as a basis for training and education, it develops cognitive interest in different fields of knowledge and forms cooperation habits. The method of projects in practice is the innovation which the main objective is the creation for a child of conditions under which he or she will get and develop knowledge, and constructively apply it. 
The introduction into an educational process of such a technology as the method of projects assists the development of a creative personality, which complies with the social demand at present, and also promotes the active participation of parents and other family members in the educational space of a preschool educational institution.

The use of the method of projects in preschool education as one of methods of interactive training of children allows one to considerably raise the independent activity of preschool children, to develop creative thinking and the ability to independently find information on a subject or phenomenon with the help of various means and - in due course - to use this knowledge for the creation of new objects of reality.

In order to skilfully organize the projecting activity with preschool children, it is necessary that the teacher himself should demonstrate a high indicator of professional competence, using masterly modern technologies. An important role is assigned to the development of creativity, imagination, independent thinking, overcoming of psychological inertia, and so on.

The didactic sense of the projecting consists in the fact that it helps to connect teaching with life, forms research experience, develops cognitive activity, independence, creativity, ability to plan, and work in collective. Such qualities assist successful training of children at school.

\section{ROMANISED REFERENCES}

Bazova prohrama rozwytku dytyny doshkilnoho viku "Ya u switi", Ministerstvo Oswity i Nauky Ukrainy, Akademiya Pedahohochnykh Nauk Ukrainy, O. L. Kononko (ed.), "Switych”, Kyiv 2008.

Chepil, M., Dudnyk, N., Pedahohichni tekhnolohii: navchal'nyi posibnyk, Akademwydav, Kyiv 2012.

Demydova, Yu., Formuyemo piznavalnu samostiynist education starshykh doshkilnykiw, "Doshkilne wykhowannia", 2006, no. 10.

Dutkewych T.V., Osoblyvosti rozwytku spilkuvannia dorosloho i dytyny u doshkilnomu witsi, [in:] T.V. Dutkewych, Doshkilna psykholohia, Kyiv 2007.

Dytyna w doshkilni roky. Prohrama rozwytku, nawchannia $i$ wykhowannia ditey, K. Krutiy (ed.), “LIPS", Zaporizhzhia 2000.

Karatayeva, M., Wprovadzhuyemo proektny tekhnolohiyu, "Dytiachyi sadok", 2004, no. 7.

Kondratenko, R., Metod proektiv u roboti z bat'kamy, “Doshkil'ne wykhovannia”, 2008, no. 5.

Ladyvir, S., Praktychna realisatsia tekhnologii psykholoho-pedahohichnoho proektuvannia, "Dytiachyi sadok", 2007, no. 14-15.

Novyie pedagogicheskiye i informatsionnyie tekhnologiyi v sistiemie obrazovaniya, E.S. Polat (ed.), "Akademiya", Moskva 2009.

Pirozhenko, T.O., Zhyttiediyalnist' dytyny yak tsikava ta zmistovna podiya, "Doshkil'ne wykhovannia", 2006, no. 9.

Proektni tekhnolohii u DNZ (DNZ = PEI, preschool educational institutions), Compiler: Burakova Yu. D., "Osnova" Publishing House, Kharkiv 2009. 


\section{STRESZCZENIE}

Artykuł opisuje psychologiczno-pedagogiczną metodę projektu w procesie działalności pedagoga z dziećmi w wieku przedszkolnym. Stosowanie tej metody przez nauczycieli wynika z aktualnej potrzeby wprowadzania innowacji w proces rozwoju dzieci. Używanie jej jest także zdeterminowane wymaganiami stawianymi nauczycielom w organizacji procesu nauczania. Opisano też sposób stopniowego jej wdrażania w przedszkolu.

Słowa kluczowe: metoda projektu; edukacja przedszkolna; specjalizacja; rozwój dziecka 